\title{
Delegitimizing the Communist Past and Building a New Sense of Community: The Politics of Transitional Justice and Memory in Ukraine
}

\author{
Oksana Myshlovska
}

HCM 7: 372-405

DOI: $10.18352 / \mathrm{hcm} .561$

\begin{abstract}
This article studies the way in which the crimes of the communist regime have been dealt with since the late Soviet period, and the way the legacies of the Organization of Ukrainian Nationalists (OUN) and the Ukrainian Insurgent Army (UPA) have been subject to reevaluation. During the Soviet period, policies such as the rehabilitation of victims of mass repression were initiated from above, while the documentation of human rights violations and revelations of mass repressions and death by hunger were undertaken by the dissident movement from below. Since the late perestroika period, the focus on the crimes of the communist regime has been used by the opposition in Ukraine in the struggle for the restitution of group rights. Affirmative action concerning the Ukrainian language, culture and history was seen as the restoration of historical justice. This resulted most recently in the adoption of so-called 'decommunization' laws, which has been a controversial and contested issue in Ukraine. The article discusses the factors that shaped the way Ukraine has handled the communist past and constructed new narratives, and reflects on the reason why a 'politics of regret' has not resonated yet with political actors involved in the state legitimization struggle.
\end{abstract}

Keywords: communist past, conflict, OUN, politics of history and memory, transitional justice, Ukraine, UPA 


\section{Introduction $^{1}$}

Two decades after the fall of the Soviet Union, Myroslav Marynovych, a former Ukrainian political prisoner and dissident, observed that post-Soviet societies failed to acknowledge, investigate, condemn and repent for the crimes of the Stalinist regime, thus inhibiting their further progress. He noted the persistence of communist falsifications of history and memories which as "the toga of "a winner over Hitler" cover the ugly nakedness of the Stalinist regime, the crimes of which were not smaller than the crimes of the Hitler regime'. Marynovych called for a trial of communist crimes, the identification of perpetrators and acknowledgement of common guilt by all people who 'worshiped the communist animal'. In case of Russia this applied also to repentance for the use of communist doctrine to pursue its imperial ambitions. ${ }^{2}$

A long and complex process of dealing with past injustices started in the I950s with a de-Stalinization policy involving party-controlled restitution measures from above: the partial rehabilitation of victims of Stalinist repression and the consideration of 'blank spots' of history. A dissident movement that emerged in Soviet Ukraine in the I96os and I970s focused on the documentation of testimonies of political prisoners and the crimes of the communist regime. During the late perestroika period (I988-I99I), part of the Communist Party nomenklatura and the dissident movement coalesced around a common agenda acknowledging past injustices and the need for restitution and affirmative action to redress past grievances.

The communist regime in Ukraine seems to have received its definite trial after the Euromaidan protests in 20I3-4. The Ukrainian parliament adopted the four so called 'decommunization' laws on 9 April 2015, ${ }^{3}$ one of which condemned the communist and Nazi totalitarian regimes and prohibited propaganda of their symbols. The main justification of the law was that the regimes murdered between I4 to I6 million people in Ukraine, and that the Ukrainian state wished to dissociate itself from any totalitarian practices. Furthermore, the law was legitimized by security considerations in the context of the ongoing conflict in Eastern Ukraine. The lead author of the laws and the new head of the Ukrainian Institute of National Memory (UINM) appointed during the post-Euromaidan period, Volodymyr Vyatrovych, justified the laws in the following way: 
The persistent totalitarian past still impedes the development of Ukraine into a European democratic state, because Putin's aggression against Ukraine relies on the islands of 'Sovietness', which due to historical circumstances are mostly left in the Donbas and Crimea. These are mainly the persons who have Soviet values (not the Russians or Russian speakers as claimed by the Russian propaganda) who currently staff terrorist groups in the so-called LNR and DNR. So, the question of the decommunization of Ukraine today is a matter of not only cultural policy, but also of security policy. ${ }^{4}$

When reflecting on the results of the decommunization laws one year later, President Petro Poroshenko highlighted their security and reparative function: 'We have to complete decommunization because it is a matter of Ukrainian national security. It is also our responsibility for the future and a moral duty to the millions and millions of Ukrainians exterminated by Bolshevism'. ${ }^{5}$ Finally, the laws were justified by the earlier decommunization experiences of Central and Eastern European states, as well as the emerging European and international norms related to the condemnation of totalitarian regimes and the need to deal with human rights violations committed by them.

Together with the law condemning the communist totalitarian regime, another law in the package of the four decommunization laws defined the officially-approved genealogy of Ukrainian statehood. It affirmed the commemoration of the national liberation movement considered central in the attainment of national statehood, and made it illegal to deny the legitimacy of 'the struggle for the independence of Ukraine in the twentieth century'. ${ }^{6}$ The law unambiguously excluded the period of Soviet Ukrainian statehood from the Ukrainian state-building process. One of the most controversial components in the struggle for independence has been the re-evaluation of the legacy of the nationalist organizations OUN (the Organization of Ukrainian Nationalists) and UPA (the Ukrainian Insurgent Army). These had emerged in interwar Poland and then in Nazi-occupied Western Ukraine, with the purpose of fighting for an independent Ukrainian state.

About seventy foreign and Ukrainian scholars sent an open letter to the President of Ukraine and the Chairman of the Ukrainian parliament asking not to sign the draft laws in April 20I5. They considered most problematic the inclusion of groups such as the OUN and UPA as 'fighters for Ukrainian independence': 
Not only would it be a crime to question the legitimacy of an organization (UPA) that slaughtered tens of thousands of Poles in one of the most heinous acts of ethnic cleansing in the history of Ukraine, but also it would exempt from criticism the OUN, one of the most extreme political groups in Western Ukraine between the wars, and one which collaborated with Nazi Germany at the outset of the Soviet invasion in I94I. ${ }^{7}$

The link between the crimes of the communist regime and the re-evaluation of legacies of these extreme nationalist organizations as part of 'recovery history' had already been made by the Ukrainian dissident movement in the I970s. This article studies the way this connection has evolved since the late Soviet period.

In what follows, I will examine the factors that have defined the ways Eastern European countries have dealt with their communist past, such as the relationship between the regime and the opposition during the communist and post-communist periods, the regime's approach to ensuring societal compliance and the pre-communist levels of political pluralism. I will then consider the role of these factors in shaping the politics of transitional justice and memory in Ukraine. Also, I will look at the role of different regional levels of legitimacy of Soviet rule in Western Ukraine and the rest of Ukraine in the pursuit of transitional justice and a politics of memory. Finally, I will discuss the 'politics of regret', the critical examination of the past combined with a focus on the victims on both sides of the conflict, which became the European path to post-war reconciliation. In conclusion, I will offer some reflections on why this has not resonated yet with the parties involved in the state legitimization struggle in Ukraine, and reflect on the implications of legislation of history for conflict transformation and reconciliation.

\section{Dealing with Difficult Pasts in the Post-Communist Context}

Since the I990s, the idea that societies emerging from conflict and authoritarian rule needed to work through their difficult pasts and investigate and redress past violations of human rights for successful transition and the construction of a peaceful future has become widely accepted. ${ }^{8}$ The right to truth and reparative justice for victims has gradually been 
codified as part of European and international law. Olick holds that post-war Western societies have adopted a politics of regret for historical injustices and reparations associated with it, which demand a critical examination of the past, as a new principle of political legitimation instead of the 'heroic golden ages' type of the pre-World War I era. ${ }^{9}$

For Olick, the discourse of universal human rights which advocates reparation, apology and acknowledgement to restore the dignity of victims and to deter new outbreaks of inhumanity has contributed to the emergence of this politics. ${ }^{10}$ On the one hand, under the pressure of Eastern European countries, European and global institutions have condemned the crimes of the communist regime in official declarations that unravelled earlier consensus about a special role of the Holocaust in European memory. On the other hand, the Eastern European countries have been pressured to espouse the Western European approach of regret which stipulates a critical re-examination of their own national past. The investigation of local involvement in the Holocaust and the acknowledgement of its significance have become one of the requirements for countries of the region to join the family of European states. ${ }^{I I}$

As part of transitional justice measures, Eastern European states have implemented a variety of policies to investigate and prosecute the crimes of the communist era. Studies about the dealing with the communist past in Eastern Europe have focused on lustration, the opening of secret police archives, rehabilitation and compensation of victims of mass repressions and other types of transitional justice. ${ }^{12}$ The key questions in this research have been to explain factors shaping different approaches to dealing with the communist past and pursuing historical justice. Furthermore, scholarly attention has concentrated on the relationship between transitional justice and democratization. ${ }^{13}$ The coming to terms with the communist past has also included history commissions, national remembrance institutes, rewriting of history textbooks, museums of totalitarianism and communist theme parks. ${ }^{14}$

Stan has argued in what is one of the most comprehensive comparative studies on transitional justice in Eastern Europe and the former Soviet Union that the differences in the nature of transitional justice between countries of the region are rooted in the relationship between the regime and its opposition during the communist and postcommunist periods (the strength of the opposition), the communist regime's dominant methods for ensuring societal compliance with 
its rule (repression or co-optation) and the pre-communist levels of political pluralism ${ }^{15}$. Nedelsky's comparative study of two other countries that shared a communist past, but have differed in the way they approached the Soviet past (the Czech Republic and Slovakia) studies why the Czech Republic chose to 'prosecute and punish', while Slovakia chose to 'forgive and forget'. Nedelsky explains this by the level of political legitimacy of the former communist regime. The lower level of legitimacy of the Soviet regime in the Czech Republic has been explained by higher levels of repression. ${ }^{16}$

Jaskovska and Moran have argued that homogeneity was a key explanatory factor of difference in the approaches to lustration between Latvia and Estonia, on the one hand, and Lithuania, on the other. Latvia and Estonia have not adopted lustration laws as they excluded the Russian minority from the political scene following the adoption of citizenship laws, and the reformed Communist Party never became a strong political force in those countries. Lithuania has adopted inclusive citizenship laws and saw the re-emergence of reformed communists, which according to Jaskovska and Moran explains the adoption of the lustration laws in the country with the aim of dealing with communist rivals. ${ }^{17}$

Together with dealing with the communist past, the collapse of the communist bloc saw new states actively engaging in the creation or reinvention of national memories, pantheons of national heroes and official historical accounts and narratives as part of the nation and collective identity-building process. ${ }^{{ }^{8}}$ Tucker has termed the production of history for nation-building purposes 'therapeutic history', and argued that it became prevalent in Eastern Europe after the end of communism. ${ }^{19}$ At a deeper level, the production of therapeutic history and memory has reflected the trauma of lost statehood in the past centuries and the instability of national polities situated between the Western European countries and Russia. In their transnational intellectual history view at Central Eastern Europe, Trencsényi, Janowski, Baár, Falina and Kopeček argue that 'in the case of these relatively small and often highly unstable national contexts the very existence of the polity could not be taken for granted and the political and national communities rarely if ever came to overlap. All of this could also lead to the feeling - or even psychosis - of a collective "existential" threat of disappearance'. ${ }^{20}$ 
While academic literature has tended to regard dealing with the communist past and the use of history and memories for nation-building purposes as two separate areas of investigation, the case of Ukraine examined in the present article shows that the two have been closely interlinked. Dealing with the crimes of the communist regime has been inseparable from the promotion of a narrative of Ukrainian history centred on the struggle for national liberation that delegitimizes the Soviet Ukrainian statehood and reduces the Soviet period to totalitarianism and crimes. Such narratives were mythologized and preserved by the diaspora, then transmitted to the dissident organizations, embraced by the opposition parties during the late Soviet period and the local governments in Western Ukraine and finally endorsed by the state at the national level following the change of power in the wake of Maidan in 2004 and the Euromaidan in 20I4. Both the recognition of the OUN and UPA as fighters for Ukrainian independence and the decommunization policies have been regionally dividing and contributing to internal conflict in Ukraine. Transitional justice and work of memory have taken the shape of criminalization and elimination of some difficult pasts, and state endorsement of a 'correct' and 'truthful' reading of national history instead of dialogue and critical work with both of them.

\section{Restoration of Historical Justice During the Late Perestroika Period in Soviet Ukraine}

The emergence of a dissident movement in Soviet Ukraine became possible due to a degree of liberalization in the Soviet Union, the first wave of rehabilitation of the victims of Stalinism and a partial release of political prisoners in the I950s. Dissident organizations sustained contact with the Ukrainian diaspora organizations abroad and absorbed from them some elements of the nationalist discourse that the diaspora during the Cold War recoded as anti-Soviet, anti-totalitarian and democratic. Early human rights organizations focused on the crimes committed by the communist regime in Soviet Ukraine, defined the Ukrainian people as the victims of repression and included the insurgent army based in Western Ukraine among the most important instances of national suffering.

The Ukrainian Public Group to Promote the Implementation of the Helsinki Accords was one of first human rights organizations created by 
the dissident milieu in Soviet Ukraine in the mid-I970s. It stated in its declaration of principles that while the group's goals were completely humanitarian, it could not avoid the nationality question as "most Ukrainian political prisoners have been sentenced for imagined or real nationalism' ${ }^{21}$ The movement combined the exposition of historical injustices suffered by the Ukrainian people under Soviet rule such as the famine of I932-3, political repression in the late I930s, the destruction of the Ukrainian Insurgent Army and repression in the ${\text { I } 9605^{22}}^{22}$ with the reporting on violations of the Universal Declaration of Human Rights and the Helsinki Accords in Soviet Ukraine. The Helsinki group was banned soon after its creation and all thirty-seven members who joined the group experienced some form of persecution.

Attempting to rejuvenate the Soviet regime and distance himself from the older Soviet elites (above all the security apparatus), Mikhail Gorbachev restarted the process of exposing the crimes of the Stalinist regime, filling the 'blank spots' of history and rehabilitating the victims of past repressions. Rehabilitated dissidents and former political prisoners began to play an important role in shaping the political agenda in Soviet Ukraine, casting themselves as voices untainted by collaboration with the repressive Soviet regime. In August I987, Vyacheslav Chornovil, a dissident and a former political prisoner who would chair the most important opposition movement in Ukraine in I989, sent an open letter to Gorbachev, in which he regretted that the declared democratic revival of Soviet society as a result of glasnost and perestroika remained 'a revolution of words'. ${ }^{23}$

In this letter, Chornovil also highlighted 'blank spots' of Ukrainian history which had to be brought to light as '[a]ttempts at writing the twentieth century history of Ukraine solely as the history of the Bolshevik Party in Ukraine [which] have resulted in silence on many facts concerning the social and national struggle of the Ukrainian nation in the first decades of the twentieth century....' One 'blank spot' Chornovil mentioned was 'the partisan and underground struggle' in Western Ukraine in the I940s and early I950s that was 'the beloved theme of Soviet propaganda, which has for decades specialized in exposing "Ukrainian bourgeois nationalism". In relation to the movement, Chornovil argued that 'We need to take a calmer and broader look, to find out the reasons for this mass popular movement in which hundreds of thousands of people, not bandits, initially took part, supported by 
the majority of the population of Western Ukraine'. He concluded that he did not "view certain aspects of the national movement of 1920-40 in Western Ukraine in a simplified way ... the right to critical views I earned in prison, where I spent time together with participants in this movement'. ${ }^{24}$

The Ukrainian Helsinki Union was founded in I988 as a federation of self-governing human rights defence groups, which had as its declared purpose the defence of national rights, above all, the defence of the right of nations to self-determination as provided in Article I of the International Covenant on Civil and Political Rights, because 'the nation is the sole natural social environment in which an individual can fully develop his abilities and fulfil his purpose on this earth'. ${ }^{25}$ The Union claimed that the government of the Ukrainian SSR, which had never been a truly sovereign body, nor the Communist Party of Ukraine, which was merely a subdivision of the Communist Party of the Soviet Union, had the power or the inclination to 'protect the population of Ukraine from total famine, from the barbaric destruction of the nation's productive forces and intellectual potential, from the denationalization of Ukrainians and the non-Russian minorities, and from artificial changes in the ethnic composition of Ukraine'. The claim was put in the context of 'outright genocide and the continuing ethnocide of the indigenous population of Ukraine'.

Thus, the Union held that the restoration of Ukrainian statehood was fundamental to secure the economic, social, cultural, civil and political rights of both the Ukrainian people and national minorities. ${ }^{26}$ Some persons associated with the OUN and UPA, for example Yuriy Shukhevych, the son of the UPA commander Roman Shukhevych, were among members of the Helsinki group. They argued for the inclusion of nationalist organizations among the historical injustices committed by the Soviet Union and raised now by the dissident movement.

The opposition movement consolidated into the People's Movement of Ukraine for Perebudova [Rukh] in September I 989. The Programme of the Movement adopted in I989 started with a verdict of the existing system, which it described in terms of an acute crisis resulting from the forced introduction of the Stalinist model of totalitarian pseudosocialism. It provided an overview of the historical development of Ukrainian statehood and the suffering of the Ukrainian people in the twentieth century. Rukh declared as its goal the construction of a 
democratic and humanistic society in Ukraine and the prevention of denationalization. ${ }^{27}$

The opposition organizations and then political parties that emerged during the late perestroika period addressed in one way or another the 'national question' in relation to past injustices; some questioned the legitimacy of the communist regime in Ukraine. The opposition parties held that the revival of the Ukrainian nation, its language, historical memory and traditions as well as those of other nationalities, that followed the decades of denationalization, was a form of restitution for past injustices. Some organizations also argued that national statehood was a natural form for the survival of the Ukrainian people. Another important characteristic of the early discourse of the opposition was a combination of the national liberation struggle with democratization and the fight for human rights and historical justice.

\section{Undoing the Soviet Past and Forging a New Political Memory in Western Ukraine}

As of the late I980s, Western Ukraine and the rest of Ukraine followed different paths in dealing with the communist past. Soviet rule in what would become Lvivska, Ternopilska, Ivano-Frankivska, Zakarpatska, Chernivetska, Volynska and Rivnenska oblasts of Ukraine was established during World War II. According to the survey conducted in the framework of the Region, Nation and Beyond project in 20I3, support for the recognition of the OUN and UPA as fighters for the independence of Ukraine was the highest in three oblasts in Western Ukraine (Fig. I): $90.6 \%$ of the population in Ivano-Frankivska oblast, $92.4 \%$ in Lvivska oblast and $94.5 \%$ in Ternopilska oblast. The two nearby oblasts, Volynska and Rivnenska, the region of UPA emergence and action, come next in terms of support for the OUN and UPA. At the same time, the recognition of the two nationalist organizations as 'fighters for Ukrainian independence' was supported only by $32.4 \%$ of the population nationwide, and $37.4 \%$ opposed such a proposition in 2013 . $80.6 \%$ in Donetska oblast opposed it. ${ }^{28}$

Furthermore, another survey conducted by the Razumkov Center in December 2015 in all regions of Ukraine except for Crimea and the non-government controlled areas of Luhanska and Donetska oblasts 


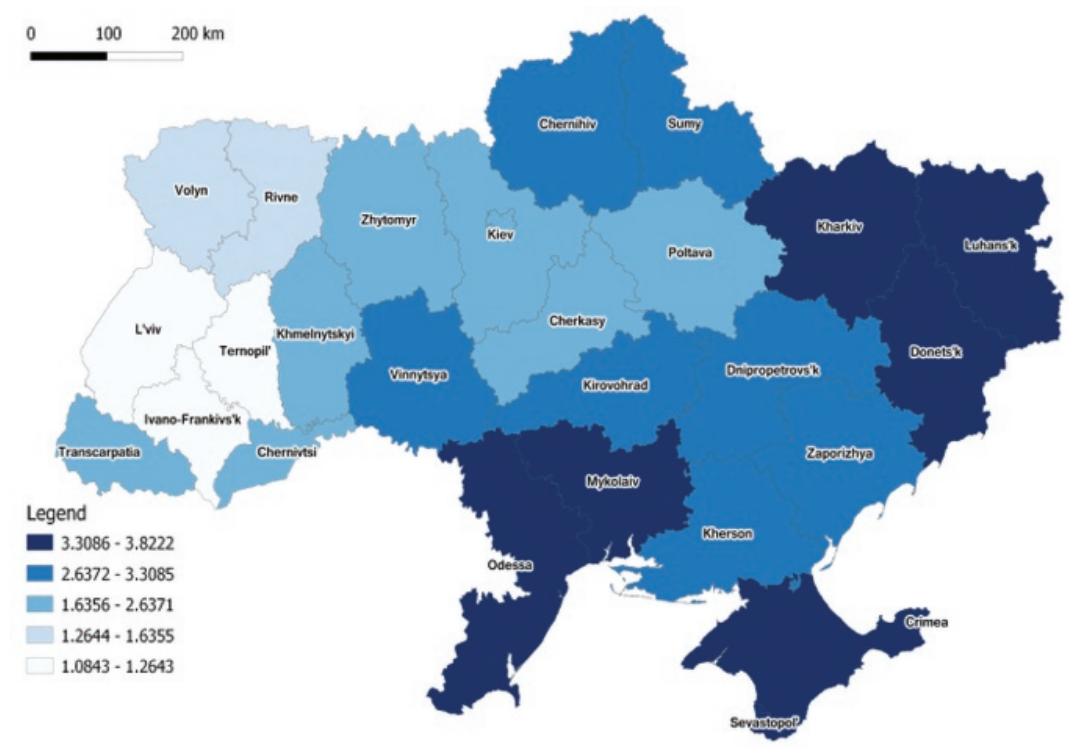

Figure I. Negative answers to the question 'Do you consider the OUN and UPA as fighters for independence of Ukraine?' (Source: Survey 20I3; see note 28).

showed that Western Ukraine (comprising Lvivska, Ternopilska, Ivano-Frankivska, Zakarpatska, Chernivetska, Volynska and Rivnenska oblasts) stood out in Ukraine with the highest share (27.9\%) of those who define the Ukrainian nation in cultural terms (the use of Ukrainian language, respect for national traditions, and education in accordance with such traditions) and the lowest share of those who define the Ukrainian nation in civic terms (Ukrainian citizenship, irrespective of ethnic and linguistic background). The region also shows the highest support for decommunization. At the same time, Western Ukraine had the highest share of those who considered themselves European (56\% vs $29 \%$ nationwide). ${ }^{29}$

Several parties created in the late I980s and early I 990 s in Western Ukraine integrated certain historical memories into their programmatic goals. They articulated the vision of Ukrainian history as centred on the national liberation struggle that linked the Kyivan Rus, the Cossack state, the UNR (Ukrainian People's Republic) and ZUNR (Western Ukrainian People's Republic), and the OUN and UPA struggle, while qualifying the period of Soviet rule as occupation and the 
Soviet Ukrainian state as illegitimate. The programme of the Ukrainian National Party created in Lviv in October I 989 considered the aggression of Russia against the Ukrainian People's Republic in I9I 8 illegal and saw it as the beginning of the period of occupation. It regarded the restoration by the OUN of the Ukrainian Independent United State on 30 June I94I, during Nazi occupation, as well as the fight of the UPA on two fronts against Nazi Germany and Bolshevik Russia, as part of a continuous fight of the Ukrainian people for state independence in the twentieth century. It declared the Ukrainian SSR as an artificial structure and a colonial administration of Ukraine..$^{30}$ Similar historical references and the statement about the invalidity of the union agreement were made by the Ukrainian Popular Democratic Party created in May 1990. ${ }^{31}$ Another party created in Lviv in April I990, the State Independence of Ukraine, which included among its members former OUN and UPA fighters, declared that it accepted as members only Ukrainians and those who were not connected to the Communist Party, and that it was based on OUN ideology. ${ }^{32}$

Following the March I990 national and local elections, deputies from the opposition parties received a majority of votes in Lvivska, Ternopilska, and Ivano-Frankivska oblasts. The Lviv Oblast Council was headed by Vyacheslav Chornovil in I990-2. The newly reconstituted bodies of local governance came into conflict with the local bodies of the Communist Party and the law enforcement bodies. On 30 March I990, as the fears of lustration of the law enforcement bodies at the local level mounted, the Presidium of the Verkhovna Rada of the Ukrainian SSR decided to resubordinate the mass media and local law enforcement bodies from the local to the central level. Due to pressures by Rukh and the demonstrations by local residents, oblast councils passed decisions to dismantle monuments to Lenin in the three biggest cities of Western Ukraine in the autumn of I 990: Ivano-Frankivsk, Lviv and Ternopil. This was followed by a wide decommunization campaign across the entire region consisting in the removal of monuments and the renaming of Soviet era toponyms.

While there were debates in the local councils about the lustration of the Communist Party nomenklatura, it was decided not to follow this path. Different levels of legitimacy of the former communist regime and the strength of the Communist Party explain the different approaches to decommunization in Western Ukraine and the rest of Ukraine. 
A generally mild approach to decommunization consisting mostly in the removal of monumental symbols of communism and the renaming of Soviet toponyms in Western Ukraine can be explained by the ethnic homogeneity of the region and a quick disintegration of the Communist Party at the regional level. At the same time, mild decommunization was accompanied by the creation of a new political memory grounded in the living cultural memory ${ }^{33}$ built around the national liberation struggle for independence, which also included the OUN and UPA struggle. In general, the nationalist underground warfare combined with cultural links with the West created a system of individual, collective, political and cultural memories that sets Western Ukraine apart from the rest of the country. ${ }^{34}$

Already during the last years of the Soviet Union, the sites related to the life of the leaders of OUN and UPA became places of pilgrimage and public commemoration. This period also saw the rebirth of a tradition instituted during the early twentieth century and popularized by the OUN during the interwar period: the erection of symbolic mounds in the memory of Ukrainians who died for liberty. This symbolized the rebirth of the cult of the 'fighters for Ukrainian independence' that combined the fighters for the Ukrainian state (Sichovi Striltsi) of the early twentieth century with the OUN and UPA fighters. After the collapse of the Soviet Union, symbolic mounds were perceived as markers of the rebirth of memories that had been repressed by the Soviet regime and the restoration of historical justice, and as symbols of the fight for an independent Ukraine. In addition to the spread of symbolic mounds, other monuments, memorials and museums dedicated to the nationalist leaders were constructed across Western Ukraine. ${ }^{35}$ The first monument to Stepan Bandera, the leader of a radical OUN faction, in IvanoFrankivska oblast was opened on I4 October I990, several days after the decision to dismantle the monument to Lenin in Ivano-Frankivsk. Local authorities, along with the clergy, nationalist organizations and political parties claiming the legacy of OUN and UPA, participated in commemorative ceremonies dedicated to the national-liberation struggle.

Claiming that post-Soviet Ukrainian independence was a legacy of the OUN and UPA struggle, the opposition movement, other parties and local authorities in Western Ukraine demanded a recognition for the OUN and UPA similar to the Soviet veterans. Some local councils 
in Western Ukraine officially recognized the OUN and UPA as fighters for Ukrainian independence and provided additional social benefits to OUN and UPA veterans. In I995-7, several oblast and rayon councils of Western Ukraine adopted legislation that recognized the UPA as a combatant in World War II and its veterans as fighters for freedom and independence of Ukraine on the territory of oblasts with the corresponding benefits from local budgets. Although the legality of the local decisions was questioned by the national prosecutor's office, the decisions have never been annulled as contradicting national legislation.

\section{Compromises at the National Level}

The opposition parties did not get a majority of votes in the national parliament following the March 1990 elections. The declaration of state sovereignty in July I990 and state independence in August I99I, after the putsch in Moscow, as well as the banning of the Communist Party of Ukraine for alleged participation in the putsch in I99I and the nationalization of its property, all became possible due to a compromise between the opposition and a number of Communist Party members. Leonid Kravchuk, a former member of the Political Bureau of the Central Committee of the Communist Party of Ukraine, won the presidential elections in December I99I. The legal succession with the Ukrainian Soviet Socialist Republic was recognized by law in I99I. A symbolic succession with the UNR declared in I9I7 took place on 22 January I 992 when Mykola Plavyuk, the president of the UNR in exile, handed over the state insignia to the first democratically elected president of post-Soviet Ukraine, Leonid Kravchuk. The Communist Party registered anew in October 1993 and later the Constitutional Court of Ukraine recognized the ban as unconstitutional.

The opposition parties and national communists agreed on some restitution measures to rectify past injustices. The Verkhovna Rada of the Ukrainian SSR adopted the Law on the Rehabilitation of Victims of Political Repressions on I7 April I99I that complemented the earlier Soviet Union-wide legislation on rehabilitation and covered the entire period between I9I7 and I99I. The law declared that 'Millions of innocent people were persecuted for their political activities, statements and religious beliefs on the basis of inhumane and anti-democratic laws 
and outright lawlessness and tyranny. An especially difficult legacy of the past is mass repressions committed by the Stalinist regime and its leaders in the republic.' The parliament condemned the past repressions and declared an intention to restore justice. ${ }^{36}$ During the debate on the law in parliament, some representatives of the opposition parties challenged the fundamental assumption of the law about the legality of Soviet statehood, as they considered the period of Soviet rule to have been one of occupation.

The political rehabilitation of victims of mass repression went hand in hand with the work of historians, publicists and civil society organizations such as Memorial, investigating the 'blank spots' of Soviet history. The topic of Soviet repression became one of extensive research areas for the Ukrainian academia. In I992, the Chairman of the Security Service of Ukraine Yevhen Marchuk, the President of the National Academy of Sciences (NAS) Borys Paton, and academician of NAS of Ukraine, Petro Tronko, sent an appeal to the state authorities demanding the establishment of multi-volume scientific and documentary publications of the victims of repression in Ukraine. Soon after the parliament approved a resolution approving the project.

This established the precedent of close cooperation between the security service and the leading national academic institutions on the questions of history. By becoming directly involved in the process of the investigation of the 'dark pages' of history, the security service wanted to maintain control over the information that was made public. Between 2002 and 20I5, the project published one hundred volumes representing all oblasts of Ukraine. Each volume includes an introductory article explaining regional particularities of repressions, the names, biographies and the circumstances of arrest of thousands of victims of mass repression from I9I7 until I99I. ${ }^{37}$ The work was based on the assumption that the analysis, based on documents and scientific research, of how the Soviet repressive machine functioned in all regions of Soviet Ukraine could serve as a guarantee that similar crimes would not repeat in the future. By the middle of 20I5, the project documented 720,000 victims of political repression in Soviet Ukraine between I9I7 and I99I.$^{38}$ A National Bank of victims of political repressions (electronic martyrologue) was also created.

Soon after the March I990 elections, members of parliament from the opposition raised the question of the official rehabilitation of OUN 
and UPA at the national level, as part of the process of the restoration of historical justice. The proposal of the opposition parties to include the OUN and UPA among organizations to be rehabilitated by the Law on the Rehabilitation of Victims of Political Repressions was not supported by parliament because of the opposition of the Communist Party. The latter, as well as other left-wing parties, have remained opponents of OUN and UPA recognition. They saw commemorations of the OUN and UPA in Western Ukraine as the desecration of the memory of tens of thousands of civilians murdered by 'OUN-UPA gangs'. 39

Also, the veteran groups have consistently opposed the revision of the Soviet narrative of the Great Patriotic War, while they feared that official recognition of the OUN and UPA would lead to a revision of their social status and benefits. In I993, parliament adopted the law on the Status of the Veterans of War that recognized as veterans all those who fought for the Soviet motherland, including secret service veterans and extermination battalions that had fought against the underground movement in Western Ukraine. After intensive debates between the opposition and the left-wing parties, the law also recognized UPA members who fought against the German-fascist occupiers of Ukraine in I94I-4, and who did not commit crimes against humanity. It did not, however, include UPA fighters who fought against the Soviet regime. $4^{0}$

After the I994 and I998 parliamentary elections, the renewed Communist Party became the most important faction in parliament. It blamed the previous government for the socio-economic decline and looting of state wealth. The post-I994 period was a battle between the parliament and president Leonid Kuchma, who was elected in I994. A new anti-communist majority was formed in parliament in 2000. This majority adopted some decisions that demonstrated a symbolic rupture with the Soviet past. It discontinued the connection with the Soviet Ukrainian parliament by deciding that the first session of parliament of independent Ukraine had begun only with the first competitive elections in March I990. It also turned 7 and 8 November, at that time bank holidays commemorating the Great October socialist revolution, into normal working days. At the same time, Kuchma supported the proposal of the Council of Veterans of Ukraine of May I994 to establish a series of awards destined for the veterans of the Great Patriotic War. 
In I999, Kuchma introduced a special medal 'To the defender of the Motherland' for the veterans of the Great Patriotic War.

While some steps were taken to redress the crimes of the communist regime in the form of documentary research and a rehabilitation of victims of mass repression, the question of criminal responsibility for the crimes remained open. There was a tacit agreement between the opposition and the former communist elites who supported the proclamation of independence not to pursue the path of retribution. Myroslav Marynovych noted that Ukrainian dissidents, including himself, who 'relinquished the right to punish our offenders' were also partly to blame for the failure to deal with the communist past. Dissidents, according to Marynovych, did not become judges because they 'believed that the lawsuit against the perpetrators of communist crimes would undermine all order in society as it would turn it into a massive revenge, slander and cynical settlement of accounts', as communism had made everyone guilty. $^{41}$

The first president of post-Soviet Ukraine, Leonid Kravchuk, saw his legacy in his ability to ensure societal peace and avoid the 'Yugoslav scenario' in Ukraine. In his memoirs, he avoided the question of his personal responsibility for the Soviet past. He considered that the very question about the repentance of the Communist Party was nonsensical because the crimes of the party were so enormous (repressions, the totalitarian regime, wars, intrusion into the interests of other peoples and wars in Afghanistan, Hungary and Czechoslovakia) that the people would not be able to forgive them. ${ }^{42}$ For him, the responsibility for the crimes was entirely with the Moscow Politburo, and he presented the Soviet Ukrainian division of the party as mere 'slaves' of Moscow. He also distanced himself from the party nomenklatura and the renewed Communist Party of post-Soviet Ukraine, blaming them for a lack of support for the independence of Ukraine and for loyalty to a non-existing state (the Soviet Union). He divided all political parties into Ukrainian and non-Ukrainian, with the Communist Party representing the latter. ${ }^{43}$ At the same time, he noted that he did not support lustration of the party nomenklatura as proposed by some 'democratic orthodox'. ${ }^{44}$ Finally, Kravchuk refuted the claims of the right-wing parties that they had successfully fought for independence. For him, this had been achieved by national communists, who had headed the process of state creation and voted for independence on 24 August I99I. ${ }^{45}$ 


\section{Construction of a 'Common National Memory' after the Orange Revolution (Maidan)}

Coming to power in 2004 on the Maidan promise to punish the 'bandits' and corrupt officials of the previous government, Viktor Yushchenko felt that he had to implement policies that showed rupture with the past. He became the first president of independent Ukraine who delegitimized the Soviet past at the national level by considering Soviet rule as a period of occupation starting in I9I 8 . Yushchenko mirrored Marynovych's views that because there had been no condemnation or a trial of communism, parades carrying portraits of Stalin could still be held in Ukraine in the second decade of the twenty-first century, while people who subscribed to ideas that killed millions of persons in I932-3 and in I937-8 could still have a seat in parliament. ${ }^{46}$

Yushchenko further developed the narrative assumed by dissidents several decades earlier, which combined the discourse of suffering during the communist totalitarian regime and of the subsequent national liberation, with a discourse of democratization and Europeanization. While associating himself with the European discourse of reconciliation and celebrating the success of Polish-Ukrainian reconciliation, Yushchenko justified the heroization of Ukrainian fighters for independence. According to Yushchenko, after years of deceitful Soviet propaganda, it was necessary to restore justice, and call heroes as such and forgive their sins. ${ }^{47}$ For him, part of the population still had views instilled in them by Soviet propaganda. He considered that Ukrainians needed to become patriots of Ukraine who loved their own language, education, culture and literature, and who had their own national memory, remembering the national heroes who created the nation and laid the foundations of its independence. ${ }^{48}$

After the break-up of the coalition with his former allies in the Orange revolution, Yushchenko had to search for a compromise with his former rival, the Party of Regions. He justified the fact that he had not fulfilled one of the Maidan promises, to prosecute those guilty of crimes during the previous regime, by referring to the need to preserve peace in the country and focus on the future. ${ }^{49} \mathrm{He}$ defined the 2004 Maidan and the 2013-4 protests as a 'civil conflict' and considered the memorandum of understanding with the opposition as a first step towards the resolution of conflicts..$^{5^{\circ}}$ At the same time, Yushchenko held 
that there could be no monuments to Lenin in Kyiv, which he regarded as symbols of Soviet occupation..$^{51}$

Yushchenko mentioned that he had proposed to President Putin that they follow the example of the Ukrainian-Polish dialogue, which led to the mutual acknowledgement of guilt and reconciliation. However, Putin said that Russia could not accept responsibility for the Soviet or tsarist government and for their mistakes. ${ }^{52}$ Yushchenko held that Russia found it difficult to accept a Christian position of reconciliation because it was an empire that historically sacralized political authority and rejected the notion of guilt. ${ }^{53}$

During Yushchenko's presidency, the state created new institutions, such as the UINM, with the mandate to promote the development of a shared national historical memory. It also introduced new commemorations related to the Holomodor, the famine of $1932-3$, and to activities of the OUN and UPA. In contrast to similar institutes in other Eastern European countries, which became central to the process of lustration and were nominally independent from the government, the UINM was created as a governmental body. Its role was limited to the development of state policy and research in the field of memory, and it had a relatively small budget and staff. The UINM assumed a bigger role with the adoption of the decommunization laws, and gained full access to the secret police archives following the Euromaidan. However, it has played no role in the process of lustration, which began in 2014 .

Furthermore, in 2005 Yushchenko initiated the celebration of I4 October as the day of the Ukrainian army and the foundation of the UPA. The Holodomor was recognized by parliament as a genocide against the Ukrainian people in 2006. The legislation about the Holodomor condemned Soviet functionaries who were its perpetrators and mandated the removal of monuments to them. Although the legislation did not list the names of perpetrators, it was invoked by some nationalistic parties as legal grounds for removing Lenin statues. A criminal case against the Soviet functionaries who "carried out the genocide in Ukraine in I932-3, as a result of which millions of citizens died' was initiated by the Security Service of Ukraine at the request of President Yushchenko in 2009. In January 20I0, the Kyiv Appellate Court heard the case and found that Stalin and several other high Soviet functionaries planned and committed genocide. The case was closed, however, because the defendants were deceased. 
On the occasion of the sixty-fifth anniversary of the creation of the UPA in 2007, Yushchenko issued a decree on commemorative measures to 'restore national memory and historic justice, strengthen societal harmony and consolidate society' ${ }^{54}$ On the same day, he issued another decree to commemorate the hundredth anniversary of Roman Shukhevych's birth, granting him the status of 'Hero of Ukraine' 'for a considerable personal contribution to the national liberation struggle for liberty and independence of Ukraine' ${ }^{55}$ As part of these measures, an exhibition dedicated to the OUN and UPA was opened at the Museum of the Great Patriotic War in Kyiv. Apart from setting up this controversial exhibition, the museum in general was 'ukrainized' by adding the Ukrainian national flag and other Ukrainian symbols (Figs. 2 and 3), and highlighting the role of Ukrainians during the war in the museum's narrative.

A stand about the OUN and UPA (Fig. 4) was added to the exhibition room dedicated to the partisan movement, offering a narrative that was similar to the way it was represented in school textbooks. It contained the

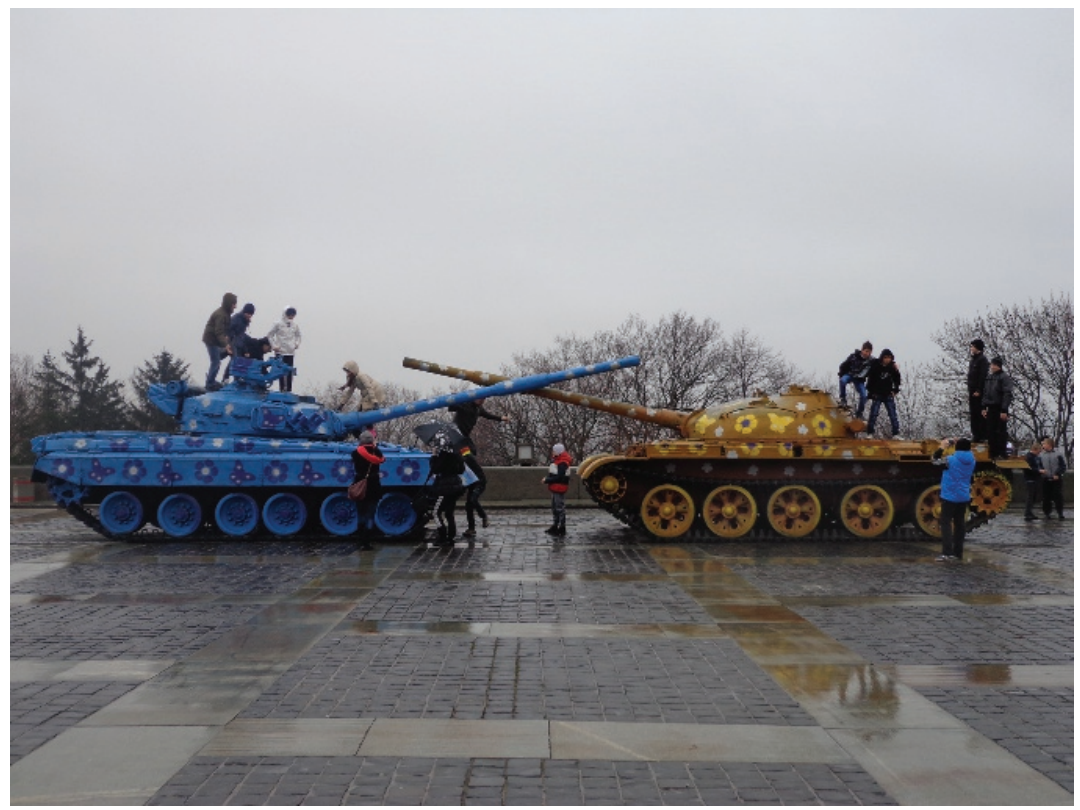

Figure 2. Two tanks at the entry to the Great Patriotic War museum painted in the colours of the Ukrainian flag (Source: photographed by the author, I3 April 20I3). 


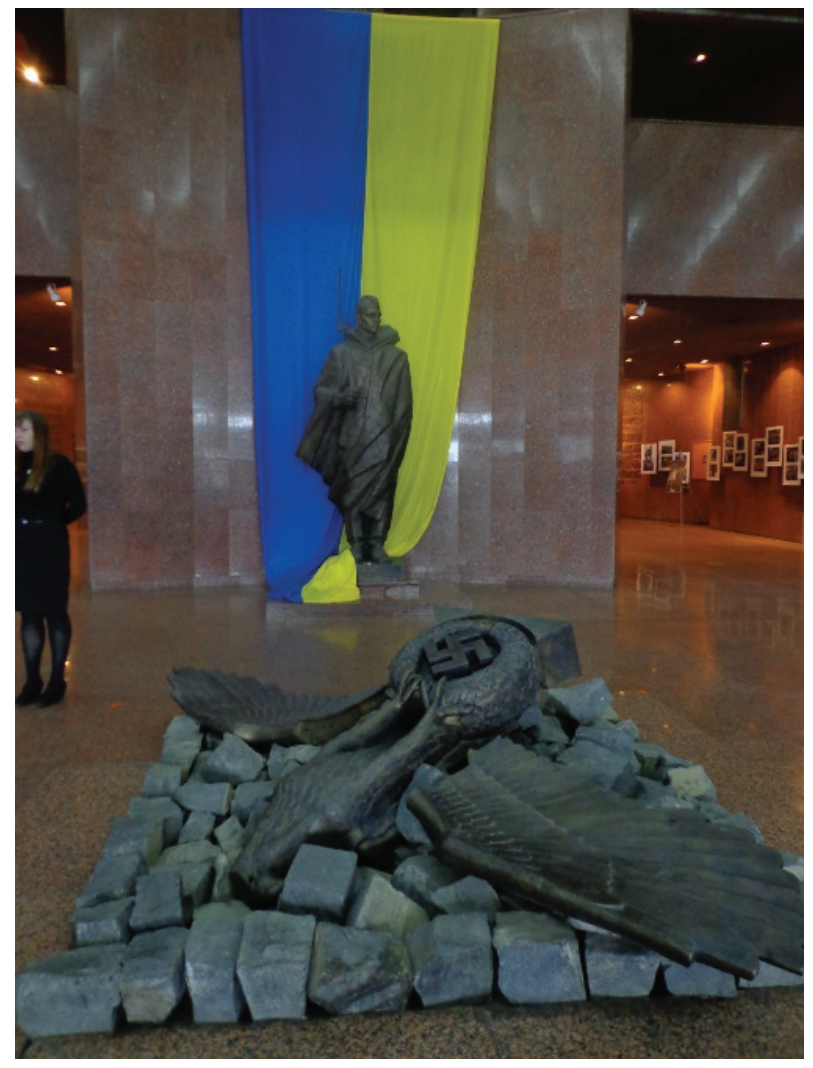

Figure 3. A Soviet soldier in the lobby of the museum in front of the Ukrainian flag (Source: photographed by the author, I3 April 2013).

photos and biographies of several prominent OUN members (excluding Stepan Bandera) and of Roman Shukhevych, some propaganda documents about the organizations, and official documents and letters by the organizations' members. In general, the stand provided little interpretation and allowed the documents to speak for themselves. The materials did not cover any controversial issues or alternative views related to the two organizations. The guided tours observed by the author in the museum in April 20I3 and October 20I6 avoided the OUN and UPA stand and went directly to a reconstructed dugout of Soviet partisans situated in the opposite corner of the exhibition room. Thus, even if the museum staff had to abide by the official pressure to introduce the OUN and UPA narrative in the museum, it could resist, ignore or subvert it in 


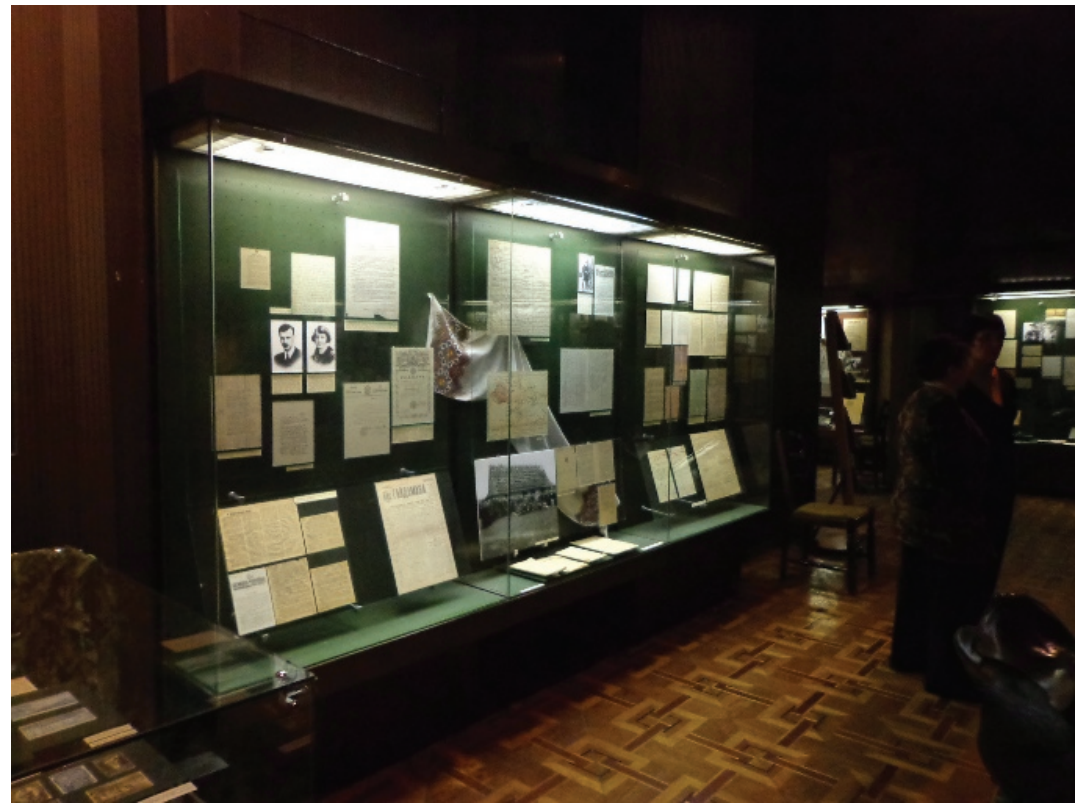

Figure 4. A stand dedicated to the OUN and UPA in Room 8, dedicated to the partisan 'Anti-fascist resistance movement of the Ukrainian people' (Source: photographed by the author, I3 April 20I3).

more subtle ways. Some members of the Communist Party of Ukraine and of the Party of Regions protested against the OUN and UPA stand. However, it was not dismantled even during the presidency of Viktor Yanukovych.

In 2008, the Liberation Movement Research Centre based in Lviv, the Security Service of Ukraine and the UINM developed a narrative about the OUN and UPA that was turned into a moving poster exhibition 'The Ukrainian Insurgent Army. The History of the Unsubdued'. The narratives of the exhibition were published as a separate brochure with Volodymyr Vyatrovych, an employee of the UINM and advisor to the Head of the Security Service at that time, as its lead author. ${ }^{56}$ The brochure included a foreword by Yushchenko, who stated that finally Ukraine was discovering its 'national memory' and 'real history' about the 'heroic struggle of Ukrainians for their own statehood', represented above all by the UPA, the history of which had been silenced, prohibited or distorted by the Soviet regime. ${ }^{57}$ In his introductory word to the 
brochure, Vyatrovych recast the history of Ukraine as the history of the fight of the Ukrainian people for independence..$^{8}$ This became the lens that defined the entire narrative and presented both OUN and UPA as heroic organizations that fought against two totalitarian systems, the Nazi and the communist. The narrative was presented as 'objective truth', based on new archival data disclosed by the Security Service of Ukraine with the hope that the information campaign about 'the truth' across Ukraine would allow to overcome the current controversies and misperceptions and to create a common national memory. The promotion of the narrative dwelled on state resources.

The most controversial decisions were taken by Yushchenko at the very end of his presidency in January 20I0. These included the recognition of Stepan Bandera as 'Hero of Ukraine' 59 and a decree 'About the commemoration of the participants in the fight for independence of Ukraine in the twentieth century'. ${ }^{60}$ Yushchenko acknowledged that the recognition and heroization of the national liberation movement at the national level was a difficult and controversial act, which would not be supported by the majority of the population. He nevertheless adopted a decree granting the title of Hero of Ukraine to Stepan Bandera during the last months of his presidency. He believed that it was his last chance to do so, as he would not be re-elected as president, and he did not expect that in the next ten to fifteen years such a decision would be adopted. ${ }^{61}$

Yushchenko hoped that his decision would make the two-thirds of the population who did not support Bandera's rehabilitation because they were 'ill-informed', change their mind.$^{62} \mathrm{He}$ also rejected the arguments of those who claimed that the OUN could not be heroized because it used violence and terrorism to achieve its goals. For him, the most important criterion for heroization was what a person had done for the nation. ${ }^{63}$ The decree 'About the commemoration of the participants in the fight for independence of Ukraine in the twentieth century' recognized a number of military formations, parties, organizations and movements that had fought for Ukrainian independence, including the OUN and UPA. The decree called for the development of teaching materials about the fight for independence in the twentieth century, the renaming of public spaces after independence fighters and the holding of commemorative ceremonies in their honour.

The decree about Bandera was followed by public debates and protests of the EU and other Western institutions. The debate involved 
Ukrainian and foreign scholars and public intellectuals specialized in nationalist organizations and the public use of history. The main contributions to the debate were published. ${ }^{64}$ At the same time, the 20 Io decree on the participants in the fight for independence of Ukraine in the twentieth century received much less public attention and criticism.

\section{Partial Undoing of the Nationalist Heroic Past and the Interregional Memory Politics During Viktor Yanukovych's Presidency}

Soon after the victory of Viktor Yanukovych in the presidential elections in 20I0, Bandera's status as the Hero of Ukraine was annulled by a Donetsk court. Furthermore, the UINM was closed and then reinstated in a downgraded status. During Yanukovych's presidency, several pieces of legislation were adopted concerning the commemoration of the Great Patriotic War, in particular the flying of the red 'flag of victory' along the Ukrainian national flag on Victory Day (9 May). The pro-Yanukovych Party of Regions also submitted a draft law to the parliament against the heroization of the OUN and UPA in 20I3. At the same time, the law concerning the Holodomor and the decrees on granting the status of Hero of Ukraine to Roman Shukhevych and on the commemoration of the fight for independence remained in force. Also, the commemorative traditions concerning the Holodomor continued across Ukraine.

During this period, memory work concerning the OUN and UPA again shifted to Western Ukraine. Local authorities protested against Yanukovych's memory politics by affirming the nationalist narrative, glorifying the struggle for independence at the local level. The Lviv City Council adopted its own calendar of important dates when the national flag was to be officially flown, which included the restoration of the Ukrainian state by the OUN during Nazi occupation (30 June), the days of victims of political repression and famine, the day of the Ukrainian Army and the UPA (I4 October) and the end of World War II in Europe (8 May), in addition to Victory Day (9 May). ${ }^{65}$ Furthermore, the Lviv Oblast Council adopted a decision that restored the title of the Hero of Ukraine to Stepan Bandera in $20 \mathrm{II}^{66}$ and created a scholarship named after Bandera 
in 20I2. ${ }^{67}$ Similar decisions were adopted by other city and village councils across Western Ukraine. In 20 I2, at the initiative of the farright Svoboda Party, the Lviv Oblast Council also banned the use of Soviet, Communist and Nazi symbols on official buildings and in mass rallies taking place within Lvivska oblast, in response to the 20I I amendment initiated by Yanukovych about the flying of the red flag. The Museum of the Liberation Struggle of Ukraine (part of the Lviv History Museum) was opened in Lviv in 2012.

The national liberation struggle and in particular the OUN and UPA narrative turned into instruments used in interregional and centreperiphery struggles. They became acts of resistance to the Yanukovych regime, which was widely seen as corrupt and anti-Ukrainian. Many new public memory elements introduced in Western Ukraine such as the celebration of the end of World War II on 8 May and the prohibition of the use of Soviet, Communist and Nazi symbols on official buildings would be transplanted to the national level after the Euromaidan. The legislation adopted at the regional and local levels in Western Ukraine was in contradiction with national legislation, but it remained unaddressed by the national bodies. Decisions violating national legislation, for example concerning the use of Russian and the exercise of local autonomy, were also adopted by some local governments in Eastern and Southern Ukraine. There were no working mechanisms able to resolve the contradictions between central and local levels, which would come to a head in the outbreak of the conflict in Eastern Ukraine.

\section{The Decommunization Laws and the 'Democratization' of Nationalist Discourse after the Euromaidan Revolution}

Following the Euromaidan protests and with the beginning of the armed conflict in Eastern Ukraine, the recognition of the OUN and UPA as fighters for independence and the elimination of the Soviet heritage became the two principal goals of the state's memory politics. As earlier during the presidency of Yushchenko, the purpose of the policies was to 'other' Russia and prove that Ukraine had a distinct (i.e. nonRussian) history and historical memory. This was believed to serve as a necessary condition for successful democratization and development. 


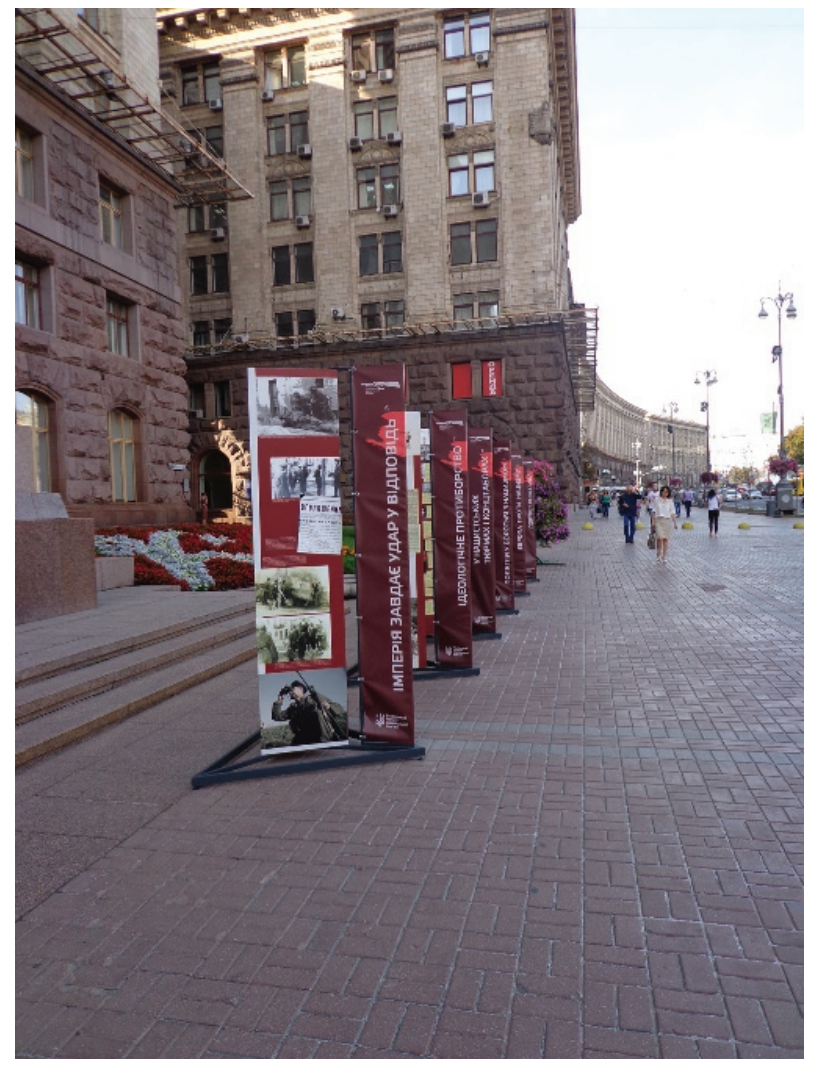

Figure 5. A moving poster exhibition 'UPA - the answer of the unsubdued people' next to the building of the Kyiv City Council (Source: photographed by the author, I2 September 20I7).

Furthermore, in the condition of war, the politics of memory was presented as a matter of national security.

In September 20I4, President Poroshenko stated that although the issue of OUN and UPA had in the past divided Ukraine, in times of war it would be most appropriate to recognize these organizations as role models of heroism. ${ }^{68}$ All major initiatives in the field of memory initiated by Yushchenko and by local authorities in Western Ukraine during the presidency of Yanukovych were reinforced during Poroshenko's presidency. In 20 I4, the UPA Day on I4 October was selected to replace the Day of the Defender of the Fatherland (23 February), which had been the Day of the Soviet Army in Soviet times. ${ }^{69}$ The UINM further 
expanded the practice of moving poster exhibitions dedicated to the OUN and UPA, aiming to educate citizens about the organizations during the post-Euromaidan period (Fig. 5).

The law 'About the perpetuation of victory over Nazism in the Second World War I939-1945' recoded the 'Great Patriotic War' as the 'Second World War', introduced the official celebration of 8 May as the day of reconciliation, and mentioned the UPA veterans along with the Soviet ones, thus giving them equal status. It also annulled the 2000 law on the commemoration of the victory in the Great Patriotic War adopted under Kuchma and updated by Yanukovych in 20II. While during Yushchenko's presidency, only one law on the Holodomor was passed by the parliament, while other issues related to the promotion of the national liberation struggle were affirmed through presidential decrees, during Poroshenko's presidency the parliament passed four decommunization laws as well as the lustration law that followed the outlawing of the Communist Party of Ukraine. National consolidation around the narrative of the fight for independence was presented not only as an indispensable step on the way to becoming a democratic European state, but it was also justified as a way of combatting the hybrid warfare now waged by Russia. The development and justification of the grand national narrative has been supported by the same state institutions as in Yushchenko's times, in particular the UINM and the Security Service of Ukraine.

\section{Conclusion}

History remains a fundamental means of political legitimation in postSoviet states. This explains the incessant battles around history and memory in these countries. This is one of the legacies of the imperial and Soviet pasts during which liberal democratic ways of political legitimation, such as democratic elections, were slow to emerge. Richard Pipes summarized the nature of the instrumentalization of history during Soviet times in a comment, which encapsulates the defining idea behind memory and history politics in post-Soviet countries: 'The Communists asserted that they had been chosen by history to accomplish mankind's momentous transition from a class-based society to a classless one. For this reason, the manner in which modern Russian history was presented 
and taught was to them of much greater importance than it is to societies whose legitimacy rests on a popular mandate. ${ }^{\prime}{ }^{\circ}$

The core assumption of the post-Soviet period in Ukraine has been that common historical memory, myths, values and traditions are necessary for the successful transformation of the state. This assumption has been reflected both in the state's policies and in popular beliefs. The 2015 survey conducted by the Razumkov Centre showed that the three most important things Ukrainians are most proud of include sports achievements $(73 \%)$, the history of Ukraine $(69 \%)$ and the national character of Ukrainians and their ability to fight for their state and their rights $(68 \%)$. In comparison, only $33 \%$ are proud about the fair and just attitude to different social groups and $22 \%$ of the way democracy works..$^{71}$ These popular beliefs show that while Ukrainians are divided in their attitudes to the past, they are united by the belief that history matters and are not fully convinced yet by the merits of democracy.

The specificity of the case of Ukraine is that the Soviet regime had different levels of legitimacy in Western Ukraine and the rest of Ukraine, which became the defining factor in the way Ukraine dealt with its communist past. In Western Ukraine, the opposition took the majority of votes in the first competitive elections in March I990 and the Communist Party never recovered at the regional level, therefore it was unnecessary to pursue lustration. Starting with the late perestroika period, the region pursued a mild decommunization, by removing Soviet monuments and changing Soviet toponyms. At the same time, local councils adopted legislation delegitimizing Soviet rule and officially recognizing OUN and UPA as 'fighters for Ukrainian independence' in violation of national legislation. At the national level, the proclamation of sovereignty and independence in I990 and I99I became possible due to cooperation between the opposition and 'sovereign communists', thus there was no lustration of the former party nomenklatura at the national level either. The former security services retained control over access to the secret police archives until the Orange revolution and actively participated in shaping the terms of dealing with past injustices.

Until the Orange revolution, all political leaders had to search for a compromise of sorts between political forces representing different regions and between different legitimizing narratives. They saw their legacy in the preservation of peace and mutual understanding between 
different regions. Even Viktor Yushchenko, who initiated a memory policy distinct from his predecessors and his immediate successor at the national level, had to search for a compromise with his former rival, Viktor Yanukovych. The weakening of the representation of Eastern and Southern Ukraine after the 20I4 elections and the banning of the Communist Party changed the political landscape and diminished the necessity to search for compromise. This allowed decommunization laws and the law on lustration to be adopted, which covered both the functionaries related to repressions of the Yanukovych regimes and officials associated with the crimes of the communist regime.

Some political actors, most importantly Yushchenko, have tried to adopt the European discourse of acknowledgement of past guilt and reconciliation in the process of Ukrainian-Polish reconciliation. These efforts, however, have been incomplete and inconsistent, as the "politics of regret' was accompanied by policies and statements that justified the need to commemorate and glorify heroes of the national liberation struggle and to forgive their sins. The most difficult task has been to deal with the guilt for the crimes of the communist period. For Kravchuk and Yushchenko, the responsibility for the crimes lies entirely with Moscow. The evidence collected by the dissident movement, the UINM, academia and civil society about the crimes of the communist regime has been used to delegitimize the communist regime. However, it has not led to national dialogue, and dialogue with Russia remains even more distant than when Yushchenko first attempted to start such conversations. The adoption of memory and history laws in 2015 happened after a gradual process of interregional and interstate radicalization. The legislation of history and memory, privileging some historical narratives and memories and delegitimizing others, while simplifying, hardening and fixing historical interpretations, will make the process of dialogue and reconciliation all the more complicated and lengthy.

\section{Notes}

I The author would like to thank Balázs Apor and Gertjan Plets as well as two anonymous reviewers for their helpful comments and suggestions on the earlier versions of this article. Research for this paper was undertaken in the framework of the Transcultural Contact Zones in Ukraine project administered by St Gallen University. 
2 Myroslav Marynovych, 'Hrikh komunizmu. Nam usim treba pokayatysya, yak tse zrobyly nimtsi', 27 May 20II, http://www.istpravda.com.ua/ articles/20 I I/05/27/40780/; accessed 12 January 2018.

3 'On the condemnation of the Communist and National-Socialist (Nazi) totalitarian regimes in Ukraine and the ban on propaganda of their symbols' (Law 2558); 'On access to the archives of repressive organs of the Communist totalitarian regime I9I7-I99I' (Law 2540); 'On the legal status and commemoration of the fighters for the independence of Ukraine in the twentieth century' (Law 2538-I); and 'On the perpetuation of victory over Nazism in the Second World War I939-I945' (Law 2539).

4 Volodymyr Vyatrovych, 'Dekomunizatsiya i akademichna dyskusiya', May 20I5, http://krytyka.com/ua/solutions/opinions/dekomunizatsiyai-akademichna-dyskusiya\#sthash.128ZHUPE.dpuf; accessed 8 October 2017.

5 Ofitsiyne internet-predstavnytstvo Prezydenta Ukrayiny, 'Vystup Prezydenta na tseremoniyi vshanuvannya pamyati zhertv politychnykh represiy u Natsionalnomu istoryko-memorialnomu zapovidnyku 'Bykivnyanski mohyly', 20I6, http://www.president.gov.ua/news/vistupprezidenta-na-ceremoniyi-vshanuvannya-pamyati-zhertv-37I04; accessed 15 January 2018.

6 Verkhovna Rada Ukrayiny. Zakon vid 09.04.20I 5 3I4-VIII (2538-I) 'Pro pravovyi status ta vshanuvannya pamyati bortsiv za nezalezhnist Ukrayiny u XX stolitti'.

7 David R. Marples, 'Open Letter from Scholars and Experts on Ukraine Re. the So-Called 'Anti-Communist Law", Krytyka, April 20I5, http:// krytyka.com/en/articles/open-letter-scholars-and-experts-ukraine-re-socalled-anti-communist-law; accessed 15 January 2018.

8 Lavinia Stan and Nadya Nedelsky (eds), Encyclopedia of Transitional Justice, 3 Vols. (Cambridge, 2013).

9 Jeffrey Olick, The Politics of Regret (New York, 2007).

Io Ibid., I 26.

I I James Mark, The Unfinished Revolution: Making Sense of the Communist Past in Central-Eastern Europe (New Haven, 20Io); Eva-Clarita Pettai and Vello Pettai, Transitional and Retrospective Justice in the Baltic States (Cambridge, 2015).

I2 Samuel Huntington, The Third Wave (Norman, I99I); Eva Jaskovska and John P. Moran, 'Justice or Politics? Criminal, Civil and Political Adjudication in the Newly Independent Baltic States', Journal of Communist Studies and 
Transition Politics 22(4) (2006) 485-506; Pettai and Pettai, Transitional and Retrospective Justice; Lavinia Stan (ed.), Transitional Justice in Eastern Europe and the Former Soviet Union: Reckoning with the Communist Past (Abingdon, New York, 2009); Stan and Nedelsky, Encyclopedia of Transitional Justice, 3 Vols; Lavinia Stan and Nadya Nedelsky (eds), Post-Communist Transitional Justice: Lessons from Twenty-Five Years of Experience (New York, 20 I5); Helga Welsh, 'Dealing with the Communist Past: Central and East European Experiences after I990', Europe-Asia Studies 48 (3) (I996) 4I3-28; Kieran Williams, Fowler, Brigid and Alex Szczerbiak, 'Explaining Lustration in Central Europe: A 'Post-communist Politics' approach', SEI Working Paper 62 (2003).

I3 Cynthia Horne, 'The Impact of Lustration on Democratization in PostCommunist Countries', The International Journal of Transitional Justice 8(3) (2016) 496-52 I; Natalia Letki, 'Lustration and Democratisation in East-Central Europe', Europe-Asia Studies 54 (4) (2002) 529-52; Stan and Nedelsky, Post-Communist Transitional Justice.

I4 Péter Apor and Oksana Sarkisova, Past for the Eyes: East European Representations of Communism in Cinema and Museums after I989 (Budapest, New York, 2008); Mark, The Unfinished Revolution; Stan and Nedelsky, Encyclopedia of Transitional Justice, 3 Vols; Maria Todorova (ed.) Remembering Communism: Genres of Representation (New York, 2008).

I 5 Stan, Transitional Justice in Eastern Europe.

I6 Nadya Nedelsky, 'Divergent Responses to a Common Past: Transitional Justice in the Czech Republic and Slovakia', Theory and Society 33(I) (2004) 65-I I 5.

I7 Jaskovska and Moran, 'Justice or Politics?' .

I 8 Balázs Trencsényi, Maciej Janowski, Monika Baár, Maria Falina and Michal Kopeček, A History of Modern Political Thought in East Central Europe, Vol. I Negotiating Modernity in the 'Long Nineteenth Century' (Oxford, 20I6); Michael Bernhard and Jan Kubik (eds), Twenty Years After Communism: The Politics of Memory and Commemoration (Oxford, 20I4); Uilleam Blacker, Alexander Etkind and Julie Fedor (eds), Memory and Theory in Eastern Europe (New York, 2013).

I9 Aviezer Tucker, Our Knowledge of the Past: A Philosophy of Historiography (Cambridge, 2004).

20 Trencsényi, Janowski, Baár, Falina and Kopeček, History of Modern Political Thought, I2. 
2 I The Ukrainian Helsinki Group. Five Years of Struggle in Defense of Rights (Baltimore, I98I) I I.

22 Ibid, I2-3.

23 Vyacheslav Chornovil, 'An Open Letter to the Secretary General of the Central Committee of the Communist Party of the Soviet Union M.S. Gorbachev, 5 August I987', Smoloskyp 8(37) Spring 1988.

24 Ibid.

25 'For the Record: Declaration of Principles of the Ukrainian Helsinki Union', The Ukrainian Weekly, 9 October I988, 5.

26 Ibid.

27 'Prohrama ukhvalena Ustanovchym zyizdom Narodnoho Rukhu Ukrayiny za Perebudovu, 9 September I989', Literaturna Ukrayina, 28 September I989.

28 Survey, DACH project sponsored by the Swiss National Fund Grant CRIIIIL_I35348 'Region, Nation and Beyond. A Transcultural and Interdisciplinary Reconceptualization of Ukraine' (20I3).

29 Tsentr Razumkova, 'Identychnist hromadyan Ukrayiny v novykh umovakh: stan, tendentsiyi, rehionalni osoblyvosti. Informatsiyno-analitychni materialy do fakhovoyi dyskusiyi "Formuvannya spilnoyi identychnosti hromadyan Ukrayiny: Perspektyvy ta vyklyky", 7 June 20I6, 4I.

30 In Natsionalni protsesy $v$ Ukrayini: istoriya $i$ suchasnist. Dokumenty $i$ materialy, Vol. 2 (Kyiv, I997) 55 I-3.

3 I Ibid., 568-70.

32 Ibid., 56I-2.

33 About different types of memory, see Aleida Assmann, 'Memory, Individual and Collective' in Robert E. Goodin and Charles Tilly (eds), The Oxford Handbook of Contextual Political Analysis (Oxford, New York, 2006) $2 \mathrm{IO}-24$.

34 William Risch, 'A Soviet West: Nationhood, Regionalism, and Empire in the Annexed Western Borderlands', Nationalities Papers 43(I) (20I5) 63-8I.

35 André Liebich and Oksana Myshlovska, 'Bandera Memorialization and Commemoration', Nationalities Papers 42(5) (2014) 750-70.

36 Verkhovna Rada URSR, Zakon vid I7.04.I99I № 962-XII 'Pro reabilitatsiyu zhertv politychnykh represiy na Ukrayini'.

37 Ihor Syundyukov, 'Yak funktsionuvala komunistychna represyvna mashyna?', Den, Io July 20I5, https://day.kyiv.ua/uk/library/books/ marshrut-no I-vypusk-62-retro; accessed Io November 2017. 
38 Ibid.

39 Stenohrama plenarnoho zasidannya, 6 June I99I, http://iportal.rada.gov. ua/meeting/stenogr/show/4570.html; accessed I9 October 2017.

40 Oksana Myshlovska "Establishing the "Irrefutable Facts" about the OUN and UPA: The Role of the Working Group of Historians on OUN-UPA Activities in Mediating Memory-based Conflict in Ukraine' Ab Imperio I (2018) 223-54.

4I Marynovych, 'Hrikh komunizmu'.

42 Leonid Kravchuk, Odna Ukrayina, yedynyi narod (Kharkiv, 20Io), I93.

43 Ibid., 20I.

44 Ibid., 376-7.

45 Ibid., 390.

46 Viktor Yushchenko, Nederzhavni tayemnytsi: notatky na berehakh pamyati (Kharkiv, 20I4), 495.

47 Ibid., 499-500.

48 Ibid., 507.

49 Ibid., 475.

50 Ibid., 477-8.

5I Ibid., 478.

52 Ibid., 486.

53 Ibid., 487-8.

54 Ukaz Prezydenta Ukrayiny, 'Pro vidznachennya 65-yi richnytsi stvorennya Ukrayinskoyi povstanskoyi armiyi’ vid i2.I0.2007 966/2007.

55 Ukaz Prezydenta Ukrayiny, 'Pro prysvoyennya R. Shukhevychu zvannya Heroy Ukrayiny' vid I 2 zhovtnya 2007 roku 965/2007.

56 Volodymyr Vyatrovych et al, Ukrayinska Povstanska Armiya: istoriya neskorenykh (Lviv, 2008).

57 Ibid., 3 .

58 Ibid., 4 .

59 Ukaz Prezydenta Ukrayiny, 'Pro prysvoyennya S. Banderi zvannya Heroy Ukrayiny' 46/20 Io vid 20 sichnya 20 Io roku.

60 Ukaz Prezydenta Ukrayiny, 'Pro vshanuvannya uchasnykiv borotby za nezalezhnist Ukrayiny u XX stolitti' 75/20 Io vid 28 sichnya 20 Io roku.

6I Yushchenko, Nederzhavni tayemnytsi, 499, 50 I.

62 Ibid., 501.

63 Ibid., 500.

64 Tarik C. Amar, Ihor Balynskyi and Yaroslav Hrytsak (eds) Strasti za Banderoyu (Kyiv, 20I0). 
65 Lvivska miska rada, 'Pro vykorystannya Derzhavnoho prapora Ukrayiny u m.Lvovi', 24 June 2010, 3629.

66 Lvivska oblasna rada, 'Pro Heroya Ukrayiny Stepana Banderu, Rishennya sesiyi Lvivskoyi oblasnoyi rady', 47, I3 January 20 I I.

67 Lvivska oblasna rada, 'Pro zatverdzhennya Polozhennya pro Oblasnu premiyu imeni Heroya Ukrayiny Stepana Bandery', 423, I 5 March 2012.

68 'Poroshenko porivnyav voyiniv OUN-UPA z biytsyamy ATO', 25 September 20I4, http://ukr.lb.ua/news/20I4/o9/25/280566_poroshenko_sravnil_voinov_ ounupa.html; accessed 6 October 2017.

69 Ukaz Prezydenta Ukrayiny, 'Pro Den zakhysnyka Ukrayiny’ vid I4. Io.20 I4, 806/20I4.

70 Richard Pipes, Three 'whys' of the Russian Revolution (New York, I997) 5.

7I Tsentr Razumkova, 'Identychnist hromadyan Ukrayiny'.

\section{About the Author}

Oksana Myshlovska is postdoctoral researcher at the University of Bern, where she works on the role of civil society in peacebuilding and on the history and memory politics in Ukraine, the North Caucasus and Georgia. Myshlovska has previously worked on a project with the Institute of Development Studies, Sussex University, and the Swiss Development Agency, and worked at the Graduate Institute of International and Development Studies, the University of St Gallen and the Global Studies Institute in Geneva. Her research is at the intersection of memory studies, history and peacebuilding studies in Eastern Europe with a focus on Ukraine. She has published on the management of linguistic and national diversity, history, memory and transitional justice in the post-Soviet space. Recently, she has co-edited a collaborative volume Regions without regionalism. Rethinking Ukraine's heterogeneity (Budapest: Central European University Press, 20I9). E-mail: oksana.myshlovska@graduateinstitute.ch 